\title{
Characteristics of South Korea's Geothermal Water in Relation to Its Geological and Geochemical Feature
}

\author{
Chung-Mo Lee ${ }^{1} \cdot$ Se-Yeong Hamm ${ }^{1} *$ Cholwoo Lee ${ }^{2} \cdot$ Sung-Ja Choi ${ }^{2} \cdot$ Sang Yong Chung ${ }^{3}$ \\ ${ }^{1}$ Division of Earth Environmental System, Pusan National University, Busan 609-735, Korea \\ ${ }^{2}$ Korea Institute of Geoscience and Mineral Resources, Daejeon 305-353, Korea \\ ${ }^{3}$ Department of Earth and Environmental Sciences, Pukyong National University, Busan 608-737, Korea
}

\begin{abstract}
The volcanic type of geothermal water is linked intimately to active or potentially active volcanoes and takes place near the plate boundaries. In contrast to the volcanic type, the geothermal water in Korea has a non-volcanic origin. Korea's geothermal water is classified into the residual magma (RM) type and deep groundwater (DG) type according to the criterion of $35^{\circ} \mathrm{C}$. This study reviewed the relationship between the physical and chemical features of the 281 geothermal water sources in South Korea in terms of the specific capacity, water temperature, and chemical compositions of two different basements (igneous rock and metamorphic rock) as well as the geological structures. According to the spatial relationship between the geothermal holes and geological faults, the length of the major fault is considered a key parameter determining the movement to a deeper place and the temperature of geothermal water. A negligible relationship between the specific capacity $(Q / s)$ and temperature was found for both the RM type and DG type with the greater specific capacities of the RM- and DG-igneous types than the RM- and DG-metamorphic types. No relationship was observed between $Q / s$ and the chemical constituents $\left(\mathrm{K}^{+}, \mathrm{Na}^{+}, \mathrm{Ca}^{2+}, \mathrm{Mg}^{2+}, \mathrm{Zn}^{2+}, \mathrm{Cl}^{-}, \mathrm{SO}_{4}{ }^{2-}, \mathrm{HCO}_{3}^{-}\right.$, and $\left.\mathrm{SiO}_{2}\right)$ in the DG-igneous and DG-metamorphic types. Furthermore, weak relationship between temperature and chemical constituents was found for both the RM type and DG type.
\end{abstract}

Key words : Geothermal water, Residual magma type, Deep groundwater type, Specific capacity, Geology, Chemical constituents

\section{Introduction}

Hot springs or geothermal springs can be defined as warm or hot groundwater that rises from subsurface with a significantly higher temperature than the normal ground temperature. Normal groundwater has a 1 to $4^{\circ} \mathrm{C}$ higher temperature than the surface temperature of the area, whereas the temperature of hot spring water is generally at least $\sim 5^{\circ} \mathrm{C}$ higher than the surface temperature (Kim, 2007). Article 2 of Korea's Hot Spring Law (partial revision on 21 July 2011) defines a hot spring as groundwater naturally or artificially issuing from the subsurface with a temperature of $25^{\circ} \mathrm{C}$ or higher and must have a water quality meeting the presidential regulations of the Republic of Korea.

Since ancient times, geothermal water in Korea has been known as mineral water with a temperature of $40^{\circ} \mathrm{C}$ or higher naturally discharging from underground. Geothermal water has been used for balneology starting from the Baekje Kingdom (18 BC-AD 660) (Ministry of Interior, 1988). Geothermal water in Onyang area was introduced in the book, the History of the Three Countries ('Samkuksagi'), and the other 43 geothermal water sources were recorded in sixteen old books (Kim, 2007). In addition, Dongrae, Yuseong, Onyang, Yeongsan, Pyeonghae, Pyeongju, Baekcheon, Ycheon, Goseong, Sinju, and Seongju geothermal waters are described in the book, the History of Koryeo ('Goryeosa'). Since the launch of the Hot Spring Law on 2 March 1981, many new geothermal waters, which had a temperature between 25 and $30^{\circ} \mathrm{C}$, were registered. Currently, more than 400 spas are distributed over South Korea.

*Corresponding author : hsy@pusan.ac.kr

Received:2014. 4. 3 Reviewed :2014. 4. 28 Accepted:2014.4. 28

Discussion until : 2014. 6. 30 

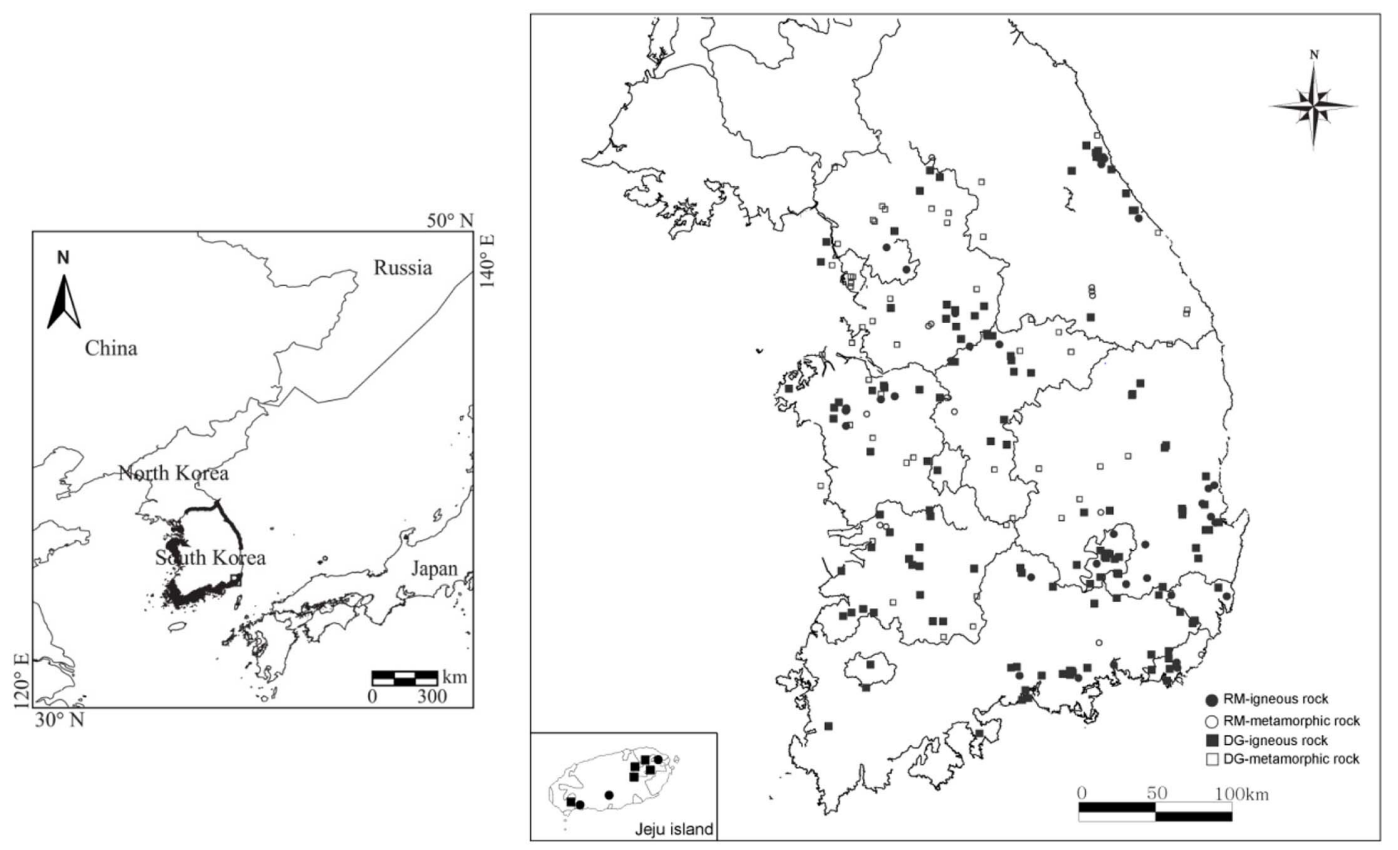

Fig. 1. Location of the residual magma (RM) and deep groundwater (DG) type geothermal waters in South Korea.

Geothermal water can be divided into volcanic type and non-volcanic type (Jeon et al., 1998). The volcanic type of hot springs is closely linked to volcanoes and plate boundaries around the world. On the other hand, the nonvolcanic type geothermal water that occurs inside continental platforms has no direct relationship with volcanic activity. Korea's geothermal water has been included in the non-volcanic type because Korea is in a stable continental platform $\sim 500 \mathrm{~km}$ away from the convergent plate boundary.

The aim of this study was to characterize 281 geothermal waters in South Korea based on the relationship among geology, geological structure, specific capacity, water temperature, and the chemical constituents (Fig. 1), and classify them into the residual magma (RM) type and deep groundwater (DG) type according to the rock types (igneous rock and metamorphic rock) (Table 1). In this study, a statistical method was applied to the geothermal waters of two different geologies (igneous rock and metamorphic rock) to characterize the specific capacity, temperature, $\mathrm{K}^{+}, \mathrm{Na}^{+}, \mathrm{Ca}^{2+}, \mathrm{Mg}^{2+}, \mathrm{Zn}^{2+}, \mathrm{Cl}^{-}, \mathrm{SO}_{4}{ }^{2-}, \mathrm{HCO}_{3}{ }^{-}$, and $\mathrm{SiO}_{2}$ (silica that is more accurately expressed as $\mathrm{H}_{4} \mathrm{SiO}_{4}$ ) of the RM and DG types.
Table 1. Numbers of geothermal water types of residual magma and deep groundwater in igneous and metamorphic rock regions in South Korea

\begin{tabular}{cccc}
\hline \hline $\begin{array}{c}\text { Geothermal water } \\
\text { type }\end{array}$ & $\begin{array}{c}\text { Metamorphic } \\
\text { rock }\end{array}$ & $\begin{array}{c}\text { Igneous } \\
\text { rock }\end{array}$ & Total \\
\hline Residual magma & 17 & 51 & 68 \\
Deep groundwater & 70 & 143 & 213 \\
$\quad$ Total & 87 & 194 & 281 \\
\hline
\end{tabular}

\section{Methods}

A total 281 geothermal waters in the regions of igneous rock (194 geothermal waters) and metamorphic rock (87 geothermal waters) in South Korea (Fig. 1) were examined to determine the statistical relationship between the specific capacity, bottom temperature of the geothermal wells, and chemical constituents of the geothermal waters. The maximum bottom temperature of the geothermal wells in each spa was considered to be the highest and representative temperature in the spa area. The mean concentrations of the chemical constituents of the geothermal wells in the each spa were considered to be representative of a spa. In addition, the properties of the geological structures were found to be related to the geothermal waters. 


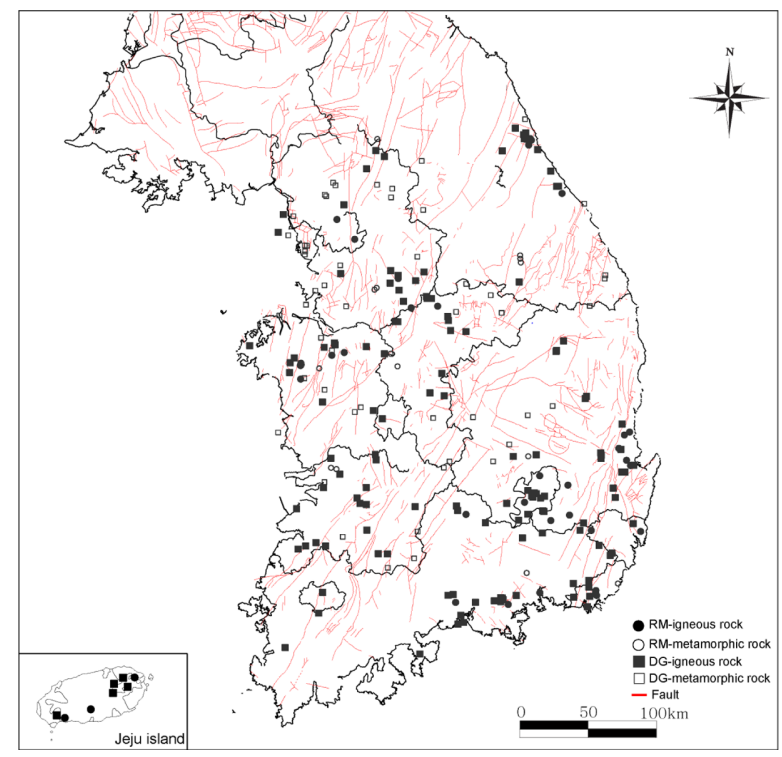

Fig. 2. Geologic structures and RM- and DG-type geothermal waters of South Korea (Korea Institute of Geoscience and Mineral Resources, 1995).

Tamanyu (1985) classified non-volcanic geothermal water in Korea into the residual magma (RM) type and deep groundwater (DG) type. According to Tamanyu's classification, in contrast to the DG type geothermal water, the RM type geothermal waters grouped into those with a bottom temperature of $35^{\circ} \mathrm{C}$ or higher. The $\mathrm{RM}$ type geothermal waters occur in the regions holding a comparatively high geothermal heat and are associated with the intrusive igneous activities typically in the late Cretaceous and early Cenozoic periods (Fig. 2). In contrast, DG type geothermal water originates from the regions with a slightly high geothermal gradient $\left(\sim 25-30^{\circ} \mathrm{C} / \mathrm{km}\right)$ and has a considerably lower temperature than the RM type (Table 2). This separation can also be justified based on the distinct temperature change patterns with depth between the two types (Fig. 3).

The 68 RM-type geothermal waters are distributed in the high permeability zones extending to a depth of several kilometers (Table 1): Yangchon spa (Moon et al., 1999), Deoksan spas (Lim et al., 1988a, 1988b 1990a, 1990b, 1990c, 1991, 1998), Ildong spa (Yum, 1991), Cheoksan spas (Sokcho (Nohak) spas (Yum et al., 1991, 1992; Kim et al., 1995), 1992; Kim et al., 1993), Seolak Plaza spas (Bae et al., 1992; Yum et al., 1994), Wonam spas (Lim et al., 1992a; Bae et al., 1993), Bugok spa (Lim et al., 1989), Suanbo spa (Chungju (Suanbo) spa (Lim et al., 1996), Jangjeon spa (Moon et al., 2000), Dongrae spa (Lim et al., 1992; Han et al., 1999), Haeundae spa (Sim et al., 2000),

Table 2. Descriptive statistics of geothermal waters of specific capacity $(Q / s)$, bottom hole temperature, and chemical compositions of the residual magma $(\mathrm{RM})$ type and deep groundwater (DG) type

\begin{tabular}{|c|c|c|c|c|c|c|c|c|c|c|c|}
\hline $\mathrm{RM}$ & $\begin{array}{c}\mathrm{Q} / \mathrm{s} \\
\left(\mathrm{m}^{3} / \mathrm{d} / \mathrm{m}\right)\end{array}$ & $\begin{array}{c}\mathrm{T} \\
{ }^{\circ} \mathrm{C}\end{array}$ & $\mathrm{K}^{+}$ & $\mathrm{Na}^{+}$ & $\mathrm{Ca}^{2+}$ & $\mathrm{Mg}^{2+}$ & $\begin{array}{c}\mathrm{Zn}^{2+} \\
(\mathrm{mg} / \mathrm{L})\end{array}$ & $\mathrm{Cl}^{-}$ & $\mathrm{SO}_{4}{ }^{2-}$ & $\mathrm{HCO}_{3}^{-}$ & $\mathrm{SiO}_{2}$ \\
\hline Max & 131.94 & 77.40 & 329.50 & 4360.00 & 1930.00 & 256.00 & 2.53 & 9110.00 & 3570.00 & 5360.00 & 72.80 \\
\hline Min & 0.86 & 35.02 & 0.23 & 0.83 & 1.21 & 0.00 & 0.00 & 0.11 & 0.17 & 6.50 & 10.50 \\
\hline Mean & 11.02 & 41.03 & 11.28 & 300.56 & 101.58 & 14.04 & 0.13 & 398.37 & 216.29 & 224.27 & 29.72 \\
\hline Median & 4.72 & 39.00 & 1.03 & 55.40 & 5.57 & 0.49 & 0.04 & 15.20 & 14.10 & 63.16 & 24.30 \\
\hline St. Dev. & 19.60 & 6.75 & 44.51 & 688.20 & 343.62 & 46.13 & 0.36 & 1387.84 & 617.50 & 715.83 & 14.86 \\
\hline Skewness & 4.89 & 2.79 & 6.51 & 4.08 & 4.68 & 4.06 & 5.65 & 5.11 & 3.91 & 6.60 & 1.10 \\
\hline Kurtosis & 28.09 & 12.49 & 45.52 & 20.46 & 22.41 & 16.75 & 36.05 & 28.61 & 16.78 & 46.80 & 0.67 \\
\hline DG & $\begin{array}{c}\mathrm{Q} / \mathrm{s} \\
\left(\mathrm{m}^{3} / \mathrm{d} / \mathrm{m}\right)\end{array}$ & $\begin{array}{c}\mathrm{T} \\
{ }^{\circ} \mathrm{C}\end{array}$ & $\mathrm{K}^{+}$ & $\mathrm{Na}^{+}$ & $\mathrm{Ca}^{2+}$ & $\mathrm{Mg}^{2+}$ & $\begin{array}{c}\mathrm{Zn}^{2+} \\
(\mathrm{mg} / \mathrm{L})\end{array}$ & $\mathrm{Cl}^{-}$ & $\mathrm{SO}_{4}^{2-}$ & $\mathrm{HCO}_{3}^{-}$ & $\mathrm{SiO}_{2}$ \\
\hline Max & 375.59 & 34.71 & 10260.00 & 6190.00 & 3240.00 & 1325.00 & 6.02 & 16400.00 & 5265.00 & 4020.00 & 85.00 \\
\hline Min & 0.27 & 24.19 & 0.16 & 0.14 & 0.64 & 0.00 & 0.00 & 0.02 & 0.08 & 0.00 & 0.00 \\
\hline Mean & 13.49 & 29.88 & 84.77 & 246.47 & 136.50 & 27.31 & 0.25 & 522.89 & 134.12 & 128.17 & 21.38 \\
\hline Median & 4.34 & 29.80 & 0.82 & 40.80 & 11.40 & 0.67 & 0.05 & 10.60 & 12.95 & 60.90 & 19.40 \\
\hline St. Dev. & 39.55 & 2.48 & 736.27 & 798.87 & 460.37 & 127.99 & 0.73 & 2072.76 & 481.06 & 324.66 & 10.71 \\
\hline Skewness & 7.02 & 0.06 & 13.27 & 5.27 & 4.78 & 7.45 & 6.35 & 4.97 & 7.28 & 9.37 & 2.59 \\
\hline Kurtosis & 54.10 & -0.67 & 183.14 & 30.10 & 24.00 & 63.56 & 44.96 & 26.71 & 67.35 & 106.05 & 10.60 \\
\hline
\end{tabular}




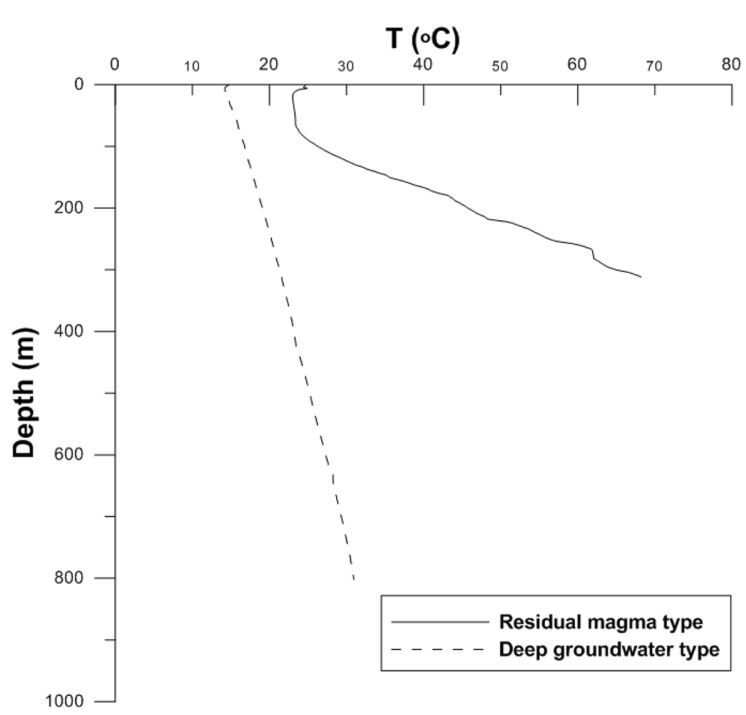

Fig. 3. Example of temperature with depth of (a) the residual magma type in Bugok spa (Lim et al., 1989) and (b) the deep groundwater type in Yesan spa (Cho and Park, 1991).

Onyang spa (Lim et al., 1987), Baekam spa (Bae et al., 1993), Yuseong spa (Lim et al., 1990), Mageumsan spa, Yongheung spa (Yum et al., 1996), HwawonsikYum spa (Kim et al., 2001), Yongam spa (Moon et al., 2001), Bukbu spa (Yum and Seong, 1994), and Sogeumgang spa (Lim et al., 1996). A total of 68 RM type geothermal waters were divided into 51 geothermal waters of igneous rock and 17 geothermal waters of metamorphic rock.

On the other hand, 213 DG-type geothermal waters are found all over the nation (Fig. 1). The DG geothermal water occurs as 143 geothermal water springs in igneous rock area and 70 geothermal water sources in metamorphic rock areas (Table 2). Both the RM type and DG type geothermal waters are related mainly to igneous rock. Kim and Choi (1998) also mentioned the close relationship between most hot springs and the Mesozoic granite in Korea.

\section{Geological characteristics of geothermal water in South Korea}

\subsection{Geological features for the occurrence of geothermal water}

Korea is composed of four tectonic blocks: Gyeonggi massif, Yeongnam massif, Okcheon fold belt, Gyeongsang sedimentary basin (Lee, 1987; Chough, 2013). The main bedrocks in Gyeonggi massif are composed of Precambrian metamorphic rocks (e.g., gneiss and schist). Yeongnam massif is also composed of Precambrian metamorphic rocks such as gneiss, schist, and quarzite. Okcheon fold belt is mainly composed of metamorphic rocks probably formed in Paleozoic. Gyeongsang sedimentary basin is formed of Cretaceous sedimentary, volcanic, and granitic rocks. Jurassic and Cretaceous granites, and Precambrian gneiss occupy about $50 \%$ of Korea.

The mean geothermal gradient and heat flow of South Korea are $25.1^{\circ} \mathrm{C} / \mathrm{km}$ and $60 \pm 11 \mathrm{mWm}^{-2}$, respectively (Kim and Lee, 2007). The southeastern part of South Korea shows high geothermal gradients more than $28^{\circ} \mathrm{C} / \mathrm{km}$ and heat flows higher than $83 \mathrm{mWm}^{-2}$ (Lim, 1995), relative to the average background surface heat flow of $67 \mathrm{mWm}^{-2}$ (Chang et al., 1970; Mizutani et al., 1970), as well as a high temperature at depth and high geothermal energy potential (Lee et al., 2010). These high heat flow values in the southeastern part of South Korea are likely to be related to the regional tectonics in the East Sea (Sea of Japan) (Kim and Lee, 2007). Tamanyu (1985) suggested that the RM type geothermal waters are potentially related to dyke swarms. RM type geothermal waters occur in the highly permeable zones extending to several kilometers in depth (Han et al., 1999; Park et al., 2006).

The RM-igneous type geothermal water is mostly associated with the relatively young igneous activity that took place from the late Cretaceous to the early Tertiary periods, typically in the southeastern part of the Korean peninsula (Fig. 1). Gyeongsang basin, which is distributed in the southeastern part of the Korean peninsula, is composed of Cretaceous sedimentary and volcanic rocks that were subsequently intruded by Bulguksa granite and dykes that were produced by the Bulkuksa igneous activity. As consequence, the source of the RM type geothermal water is the residual heat that is derived from the Bulkuksa igneous activity. Many faults and folds were also created in the Gyeongsang basin by the igneous activity. Mesothermal and epithermal ore deposits of the fissure-filling vein type that were formed in the Gyeongsang basin from late Cretaceous to early Tertiary periods are the products of Bulkuksa igneous activity (Koh et al., 2003). With the residual heat originating from Bulkuksa igneous activity, the RM type geothermal waters are governed by the existence 
of laterally and vertically extended major geological structures that can transmit high temperature from deep places. In contrast, the DG type geothermal water is linked to geological structures developed to a shallow depth and show rare evidence of noteworthy igneous activity.

On the other hand, RM-metamorphic type geothermal water is distributed in the region of the Gyeonggi massif in the northern part of South Korea, which is composed mostly of Precambrian metamorphic rock (Fig. 1).

Based on the geochemical features and temperature, the depth of the geothermal reservoir of the residual magma is inferred as $\sim 2 \mathrm{~km}$ in Bugok spa area (Park et al., 2006) or deeper in Dongrae spa area (Han et al., 1999). The inferred hot $\left(100-155^{\circ} \mathrm{C}\right)$ reservoir in Bugok spa area may be found at less than $1.8 \mathrm{~km}$ depth. In this case, geological structures should be developed to depths of several kilometers, so geothermal water rises up from a geothermal reservoir. In contrast, the DG type is not sustained by high temperature geothermal water because the geological structures are not developed to a deeper zone with any particular heat source.

\subsection{Relationship between geological structures and geothermal waters}

The seismic moment accumulation rate per unit fault length vs. locking depth (Smith-Konter et al., 2011) as well as fault length vs. surface wave magnitude (Papazachos, 1996) showed positive relationships. Furthermore, loglinear regression among seismic magnitude and surface rupture length, subsurface rupture length, and rupture area showed standard deviations of 0.25-0.35 magnitude units (Wells and Coppersmith, 1994). These manifestations show that a fault with a longer length may be developed to a deeper depth. In this study, the following geological factors were estimated for the 281 geothermal spas: the fault of the maximum length close to the geothermal hole with the highest bottom temperature/maximum depth, the distance between the longest fault and the geothermal hole, the number of sub-faults crossing the longest fault, and the total length of sub-faults (Table 3, Fig. 2). In the areas of the RM type, the lengths of the longest faults ranged from 2,546 to $140,898 \mathrm{~m}$ with an average of $49,285 \mathrm{~m}$ (Table 3 ). The distances from the hole to the longest fault ranged from 140 to $19,276 \mathrm{~m}$ with an average of $3,528 \mathrm{~m}$. In addition, the number of sub-faults crossing the longest fault were between 0 and 13 with a mean of 2.02, and the total lengths of the sub-faults reached 5,839-192,095 $\mathrm{m}$ with an average of $59,003 \mathrm{~m}$.

On the other hand, in the areas of the DG type, the lengths of the longest fault ranged from 4,779 - 140,901 m with an average of 40,874 $\mathrm{m}$ (Table 3). The distances from the hole to the longest fault ranged from 20 to $24,813 \mathrm{~m}$ with an average of $4,774 \mathrm{~m}$. In addition, the number of subfaults crossing the longest fault was between 0 and 13 (mean 1.93) and the total lengths of the sub-faults reached 2,448-236,116 m (mean 49,038 m). The faults related to the DG type exhibit normal distribution whereas the faults associated to the RM type show negatively skewed distribution that indicates the occurrence of the RM type geothermal water relates with special lengths of faults (e.g., a length of longer than $\sim 44 \mathrm{~km}$ ) (Fig. 4).

A comparison of the RM type and DG type revealed the average length of the longest fault in the RM type area to be approximately $9 \mathrm{~km}$ longer than that in the DG type area. On the other hand, the distance from the hole to the longest fault, the number of sub-faults crossing the longest fault, and the total length of the sub-faults were similar to each other in the RM type area and DG type area. This suggests that the length of the longest fault dominates both the depth

Table 3. Fault properties relative to the residual magma (RM) and deep groundwater (DG) types

\begin{tabular}{lrrrrrrrr}
\hline \hline & $\begin{array}{c}\text { Length of the longest } \\
\text { fault }(\mathrm{m})\end{array}$ & \multicolumn{2}{c}{$\begin{array}{c}\text { Distance between the longest } \\
\text { fault }(\mathrm{m}) \text { and the thermal hole }\end{array}$} & \multicolumn{2}{c}{$\begin{array}{c}\text { Nos. of sub- } \\
\text { faults }\end{array}$} & \multicolumn{2}{c}{$\begin{array}{c}\text { Total length of } \\
\text { sub-faults (m) }\end{array}$} \\
\cline { 2 - 9 } & \multicolumn{1}{c}{ RM } & \multicolumn{1}{c}{ DG } & RM & DG & RM & DG & RM & DG \\
\hline Max. & 140,898 & 140,901 & 19,276 & 24,813 & 13 & 13 & 192,095 & 236,116 \\
Min. & 2,546 & 4,779 & 140 & 20 & 0 & 0 & 5,839 & 2,448 \\
Mean & 49,285 & 40,874 & 3,528 & 4,775 & 2.0 & 1.9 & 59,003 & 49,038 \\
Median & 34,689 & 29,751 & 1,853 & 3,153 & 1.0 & 1.0 & 49,429 & 35,694 \\
St. Dev. & 40,769 & 35,785 & 4,295 & 4,825 & 2.6 & 2.5 & 48,305 & 48,323 \\
\hline
\end{tabular}



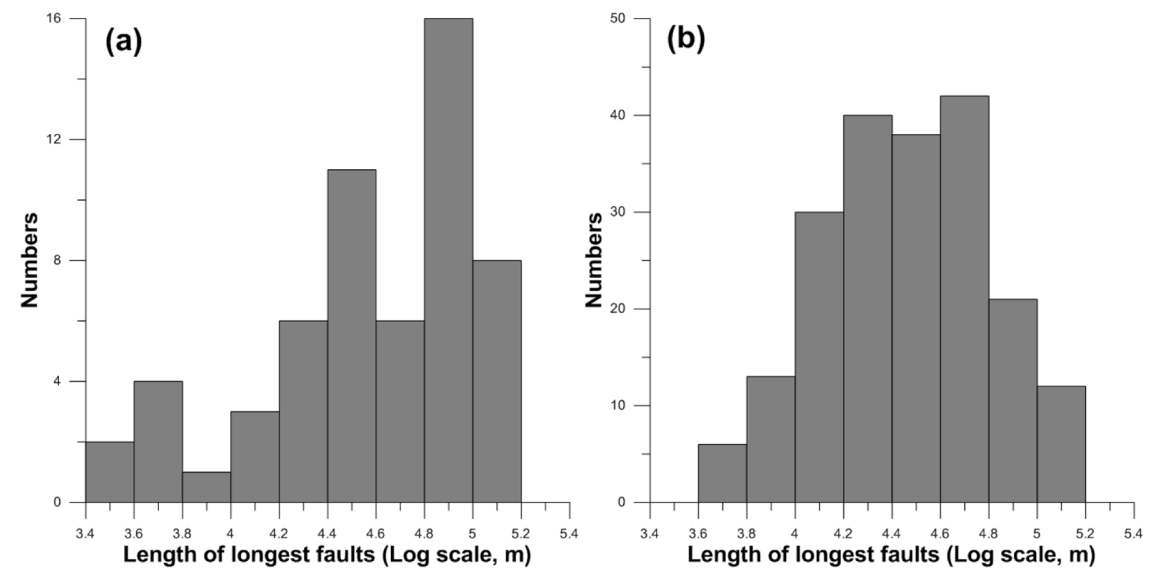

Fig. 4. Frequency distribution of the length of the longest faults near (a) RM type and (b) DG type.

Residual Magma Type

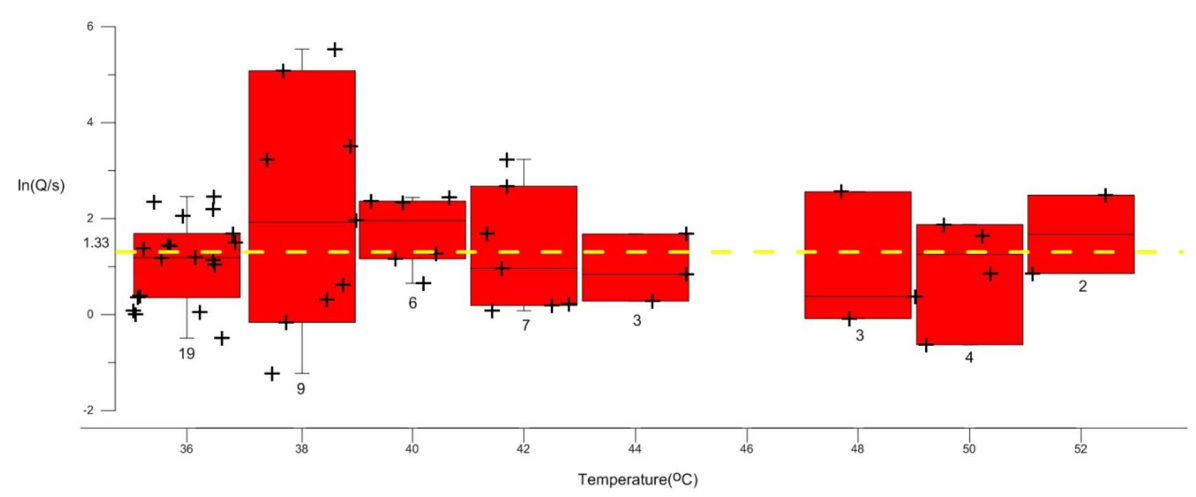

Fig. 5. Box-whisker diagrams of the specific capacity $(Q / s)$ along the bottom temperature $(T)$ for the RM-type geothermal waters.

and temperature of geothermal water. Therefore, the RM type can have a higher temperature than the DG type.

\section{Physical and chemical characteristics of geothermal water in South Korea}

\subsection{Specific capacity and temperature}

In the RM-igneous type, the specific capacity (the ratio of discharge amount to drawdown) ranged from 0.86 to 131.94 $\mathrm{m}^{3} / \mathrm{d} / \mathrm{m}$ (mean $12.16 \mathrm{~m}^{3} / \mathrm{d} / \mathrm{m}$ ) and the temperature ranged from 35.06 to $77.40^{\circ} \mathrm{C}$ (mean $40.67^{\circ} \mathrm{C}$ ) (Table 2, Fig. 5). On the other hand, in the RM-metamorphic type, the specific capacity ranged from $1.31-21.74 \mathrm{~m}^{3} / \mathrm{d} / \mathrm{m}$ (mean $7.44 \mathrm{~m}^{3} / \mathrm{d} /$ $\mathrm{m}$ ) and the temperature ranged from $35.02-51.10^{\circ} \mathrm{C}$ (mean $\left.40.67^{\circ} \mathrm{C}\right)$.

In the DG-igneous rock type, the specific capacity ranged from 0.30 to $375.59 \mathrm{~m}^{3} / \mathrm{d} / \mathrm{m}$ (mean $14.25 \mathrm{~m}^{3} / \mathrm{d} / \mathrm{m}$ ) and the temperatures ranged from 24.30 to $34.71^{\circ} \mathrm{C}$ (mean $29.90^{\circ} \mathrm{C}$ ) (Fig. 6). In the DG-metamorphic type, the specific capacity ranged from 0.27 to $284.75 \mathrm{~m}^{3} / \mathrm{d} / \mathrm{m}$ (mean $11.98 \mathrm{~m}^{3} / \mathrm{d} / \mathrm{m}$ ) and the temperatures ranged from 24.19 to $34.50^{\circ} \mathrm{C}$ (mean $29.85^{\circ} \mathrm{C}$ ).

As a result, the specific capacity of the RM-igneous type and DG-igneous type were greater than those of the RMmetamorphic type and DG-metamorphic type, respectively. On the other hand, the specific capacity of the DG type was higher than that of the RM type. This might be due to the higher frequency of fractures at a shallow depth until where the DG type is reached. Furthermore, no relationship between the specific capacity and temperature was observed for both the RM type and DG type (Fig. 7). 

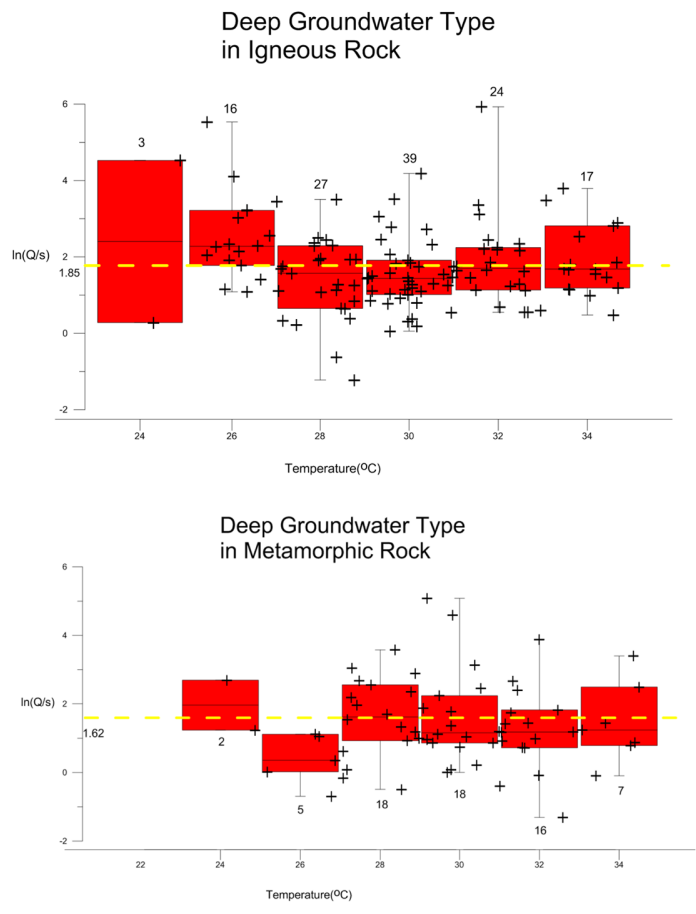

Deep Groundwater Type

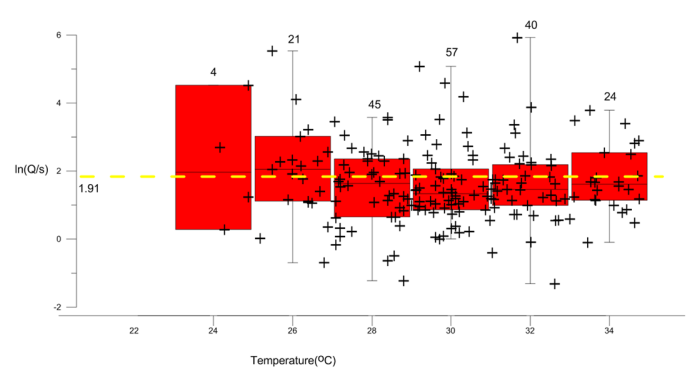

Fig. 6. Box-whisker diagrams of specific capacity $(Q / s)$ along bottom temperature for the DG-type geothermal waters in (a) igneous rock area, (b) metamorphic rock area, and (c) entire area.

\subsection{Specific capacity and chemical constituents}

In general, the chemical properties of geothermal waters and ground waters are subjected to water-rock interactions in the object areas as well as hydrochemical parameters, such as pH, Eh, temperature etc. (Kim and Choi, 1998). Pearson correlation analysis showed almost no relationship between specific capacity $(Q / s)$ and chemical constituents $\left(\mathrm{K}^{+}, \mathrm{Na}^{+}, \mathrm{Ca}^{2+}, \mathrm{Mg}^{2+}, \mathrm{Zn}^{2+}, \mathrm{Cl}^{-}, \mathrm{SO}_{4}{ }^{2-}, \mathrm{HCO}_{3}{ }^{-}\right.$, and $\left.\mathrm{SiO}_{2}\right)$ in the RM-igneous and RM-metamorphic types from which it is inferred that geothermal waters rising up from deep place possess analogous chemical composition regardless its quantity. In the $\mathrm{RM}$-igneous type, $\mathrm{Na}^{+}$showed high linearity with both $\mathrm{Ca}^{2+}(\mathrm{r}=0.872)$ and $\mathrm{Cl}^{-}(\mathrm{r}=0.921)$; $\mathrm{Ca}^{2+}$ exhibited high linearity with $\mathrm{Cl}^{-}(\mathrm{r}=0.887)$ (Table 4, Table 5). This phenomenon indicates more dissolution of $\mathrm{Na}^{+}$, $\mathrm{Ca}^{2+}$, and $\mathrm{Cl}^{-}$in deep igneous rock under high-temperature condition due to water-rock interaction.

As a result of the Pearson correlation analysis, among the chemical constituents $\left(\mathrm{K}^{+}, \mathrm{Na}^{+}, \mathrm{Ca}^{2+}, \mathrm{Mg}^{2+}, \mathrm{Zn}^{2+}, \mathrm{Cl}^{-}\right.$, $\mathrm{SO}_{4}{ }^{2-}, \mathrm{HCO}_{3}{ }^{-}$, and $\mathrm{SiO}_{2}$ ) of the RM-metamorphic type, $\mathrm{K}^{+}$ ions showed high linearity with $\mathrm{Na}^{+}(\mathrm{r}=0.983), \mathrm{Mg}^{2+}$ $(\mathrm{r}=0.863), \mathrm{Cl}^{-}(\mathrm{r}=0.854)$, and $\mathrm{SO}_{4}{ }^{2-}(\mathrm{r}=0.885)$ (Table 5). $\mathrm{Na}^{+}$ion displayed high linearity with $\mathrm{Mg}^{2+}(\mathrm{r}=0.880), \mathrm{Cl}^{-}$ $(\mathrm{r}=0.872)$, and $\mathrm{SO}_{4}{ }^{2-}(\mathrm{r}=0.898) . \mathrm{Ca}^{2+}$ ions showed high linearity with $\mathrm{Mg}^{2+}(\mathrm{r}=0.973)$ and $\mathrm{Cl}^{-}(\mathrm{r}=0.992)$. In addition, $\mathrm{Mg}^{2+}$ ions showed high linearity with $\mathrm{Cl}^{-}(\mathrm{r}=0.987)$. This correlation analysis indicates more dissolution of $\mathrm{Na}^{+}$, $\mathrm{Mg}^{2+}, \mathrm{Ca}^{2+}$, and $\mathrm{Cl}^{-}$in deep metamorphic rock under hightemperature condition due to water-rock interaction.

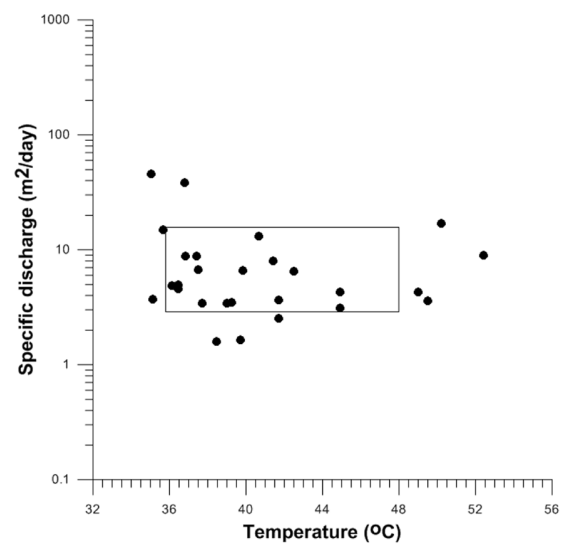

(a)

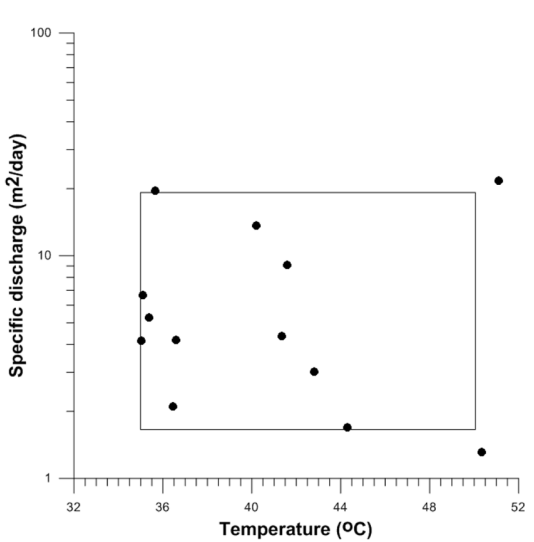

(b)

Fig. 7. Relationship between specific capacity and temperature of the residual-magma-type geothermal waters in (a) igneous rock and (b) metamorphic rock. The rectangle indicates the domain of the values within the $95 \%$ confidence interval. 
Table 4. Pearson correlation coefficient (upper value) and $p$-value (lower value) of specific capacity $(Q / s)$ and chemical constituents of the igneous residual magma type

\begin{tabular}{lccccccccccc}
\hline \hline & $\mathrm{Q} / \mathrm{s}$ & $\mathrm{T}$ & $\mathrm{K}^{+}$ & $\mathrm{Na}^{+}$ & $\mathrm{Ca}^{2+}$ & $\mathrm{Mg}^{2+}$ & $\mathrm{Zn}^{2+}$ & $\mathrm{Cl}^{-}$ & $\mathrm{SO}_{4}^{2-}$ & $\mathrm{HCO}_{3}^{-}$ & $\mathrm{SiO}_{2}$ \\
\hline $\mathrm{Q} / \mathrm{s}$ & 1 & 0.148 & -0.069 & -0.023 & -0.065 & -0.110 & 0.075 & -0.031 & -0.069 & 0.002 & 0.168 \\
& & 0.3372 & 0.6762 & 0.8897 & 0.6954 & 0.5289 & 0.6548 & 0.8497 & 0.6755 & 0.9893 & 0.3142 \\
\hline $\mathrm{T}$ & 0.148 & 1 & -0.076 & -0.102 & -0.115 & -0.034 & -0.122 & -0.075 & -0.144 & -0.027 & 0.138 \\
& 0.3372 & & 0.6315 & 0.5203 & 0.4695 & 0.8403 & 0.4548 & 0.6421 & 0.3616 & 0.8667 & 0.3955 \\
\hline \multirow{2}{*}{$\mathrm{K}^{+}$} & -0.069 & -0.076 & 1 & 0.039 & 0.086 & 0.136 & 0.590 & 0.179 & 0.071 & 0.051 & 0.168 \\
& 0.6762 & 0.6315 & & 0.8008 & 0.5746 & 0.3976 & $<.0001$ & 0.2443 & 0.6426 & 0.7445 & 0.282 \\
\hline \multirow{2}{*}{$\mathrm{Na}^{+}$} & -0.023 & -0.102 & 0.039 & 1 & $\mathbf{0 . 8 7 2}$ & 0.676 & 0.594 & $\mathbf{0 . 9 2 1}$ & 0.588 & 0.272 & -0.078 \\
& 0.8897 & 0.5203 & 0.8008 & & $<.0001$ & $<.0001$ & $<.0001$ & $<.0001$ & $<.0001$ & 0.0745 & 0.619 \\
\hline $\mathrm{Ca}^{2+}$ & -0.065 & -0.115 & 0.086 & $\mathbf{0 . 8 7 2}$ & 1 & 0.638 & 0.507 & $\mathbf{0 . 8 8 7}$ & 0.577 & 0.172 & -0.051 \\
& 0.6954 & 0.4695 & 0.5746 & $<.0001$ & & $<.0001$ & 0.0005 & $<.0001$ & $<.0001$ & 0.2634 & 0.7452 \\
\hline \multirow{2}{*}{$\mathrm{Mg}^{2+}$} & -0.110 & -0.034 & 0.136 & 0.676 & 0.638 & 1 & 0.535 & 0.468 & 0.486 & 0.783 & 0.361 \\
& 0.5289 & 0.8403 & 0.3976 & $<.0001$ & $<.0001$ & & 0.0004 & 0.0023 & 0.0013 & $<.0001$ & 0.0238 \\
\hline \multirow{2}{*}{$\mathrm{Zn}^{2+}$} & 0.075 & -0.122 & 0.590 & 0.594 & 0.507 & 0.535 & 1 & 0.427 & 0.561 & 0.275 & -0.088 \\
& 0.6548 & 0.4548 & $<.0001$ & $<.0001$ & 0.0005 & 0.0004 & & 0.0043 & $<.0001$ & 0.0743 & 0.574 \\
\hline \multirow{2}{*}{$\mathrm{Cl}^{-}$} & -0.031 & -0.075 & 0.179 & $\mathbf{0 . 9 2 1}$ & $\mathbf{0 . 8 8 7}$ & 0.468 & 0.427 & 1 & 0.355 & 0.011 & -0.107 \\
& 0.8497 & 0.6421 & 0.2443 & $<.0001$ & $<.0001$ & 0.0023 & 0.0043 & & 0.0179 & 0.9451 & 0.4965 \\
\hline \multirow{2}{*}{$\mathrm{SO}_{4}^{2-}$} & -0.069 & -0.144 & 0.071 & 0.588 & 0.577 & 0.486 & 0.561 & 0.355 & 1 & 0.129 & -0.190 \\
& 0.6755 & 0.3616 & 0.6426 & $<.0001$ & $<.0001$ & 0.0013 & $<.0001$ & 0.0179 & & 0.4049 & 0.2227 \\
\hline \multirow{2}{*}{$\mathrm{HCO}_{3}{ }^{-}$} & 0.002 & -0.027 & 0.051 & 0.272 & 0.172 & 0.783 & 0.275 & 0.011 & 0.129 & 1 & 0.370 \\
& 0.9893 & 0.8667 & 0.7445 & 0.0745 & 0.2634 & $<.0001$ & 0.0743 & 0.9451 & 0.4049 & 0.0147 \\
$\mathrm{SiO}_{2}$ & 0.168 & 0.138 & 0.168 & -0.078 & -0.051 & 0.361 & -0.088 & -0.107 & -0.190 & 0.370 & 1 \\
& 0.3142 & 0.3955 & 0.2820 & 0.6190 & 0.7452 & 0.0238 & 0.5740 & 0.4965 & 0.2227 & 0.0147 & 0.0147 \\
\hline
\end{tabular}

Table 5. Pearson correlation coefficient (upper value) and $p$-value (lower value) of specific capacity $(Q / s)$ and chemical constituents of the metamorphic residual magma type

\begin{tabular}{|c|c|c|c|c|c|c|c|c|c|c|c|}
\hline & $\mathrm{Q} / \mathrm{s}$ & $\mathrm{T}$ & $\mathrm{K}^{+}$ & $\mathrm{Na}^{+}$ & $\mathrm{Ca}^{2+}$ & $\mathrm{Mg}^{2+}$ & $\mathrm{Zn}^{2+}$ & $\mathrm{Cl}^{-}$ & $\mathrm{SO}_{4}{ }^{2-}$ & $\mathrm{HCO}_{3}^{-}$ & $\mathrm{SiO}_{2}$ \\
\hline \multirow{2}{*}{$\mathrm{Q} / \mathrm{s}$} & 1 & 0.391 & -0.308 & -0.332 & -0.095 & 0.146 & -0.314 & -0.302 & -0.291 & -0.409 & 0.140 \\
\hline & & 0.1338 & 0.3063 & 0.2676 & 0.7566 & 0.6352 & 0.2956 & 0.3154 & 0.3349 & 0.1647 & 0.6488 \\
\hline \multirow{2}{*}{$\mathrm{T}$} & 0.391 & 1 & 0.675 & 0.599 & 0.398 & 0.539 & 0.396 & 0.454 & 0.597 & 0.456 & 0.482 \\
\hline & 0.1338 & & 0.0041 & 0.0142 & 0.1265 & 0.0311 & 0.1293 & 0.0771 & 0.0146 & 0.0761 & 0.0587 \\
\hline \multirow{2}{*}{$\mathrm{K}^{+}$} & -0.308 & 0.675 & 1 & 0.983 & 0.785 & 0.863 & 0.786 & 0.854 & 0.885 & 0.470 & 0.008 \\
\hline & 0.3063 & 0.0041 & & $<.0001$ & 0.0003 & $<.0001$ & 0.0003 & $<.0001$ & $<.0001$ & 0.0663 & 0.9767 \\
\hline \multirow{2}{*}{$\mathrm{Na}^{+}$} & -0.332 & 0.599 & 0.983 & 1 & 0.803 & 0.880 & 0.803 & 0.872 & 0.898 & 0.443 & -0.104 \\
\hline & 0.2676 & 0.0142 & $<.0001$ & & 0.0002 & $<.0001$ & 0.0002 & $<.0001$ & $<.0001$ & 0.086 & 0.7026 \\
\hline \multirow{2}{*}{$\mathrm{Ca}^{2+}$} & -0.095 & 0.398 & 0.785 & 0.803 & 1 & 0.973 & 0.999 & 0.992 & 0.466 & -0.118 & -0.128 \\
\hline & 0.7566 & 0.1265 & 0.0003 & 0.0002 & & $<.0001$ & $<.0001$ & $<.0001$ & 0.0686 & 0.6623 & 0.6375 \\
\hline \multirow{2}{*}{$\mathrm{Mg}^{2+}$} & 0.146 & 0.539 & 0.863 & 0.880 & 0.973 & 1 & 0.969 & 0.987 & 0.608 & 0.017 & -0.099 \\
\hline & 0.6352 & 0.0311 & $<.0001$ & $<.0001$ & $<.0001$ & & $<.0001$ & $<.0001$ & 0.0124 & 0.9511 & 0.7139 \\
\hline \multirow{2}{*}{$\mathrm{Zn}^{2+}$} & -0.314 & 0.396 & 0.786 & 0.803 & 0.999 & 0.969 & 1 & 0.991 & 0.468 & -0.121 & -0.130 \\
\hline & 0.2956 & 0.1293 & 0.0003 & 0.0002 & $<.0001$ & $<.0001$ & & $<.0001$ & 0.0677 & 0.6562 & 0.6319 \\
\hline \multirow{2}{*}{$\mathrm{Cl}^{-}$} & -0.302 & 0.454 & 0.854 & 0.872 & 0.992 & 0.987 & 0.991 & 1 & 0.575 & -0.006 & -0.132 \\
\hline & 0.3154 & 0.0771 & $<.0001$ & $<.0001$ & $<.0001$ & $<.0001$ & $<.0001$ & & 0.0197 & 0.9823 & 0.6273 \\
\hline \multirow{2}{*}{$\mathrm{SO}_{4}^{2-}$} & -0.291 & 0.597 & $\mathbf{0 . 8 8 5}$ & 0.898 & 0.466 & 0.608 & 0.468 & 0.575 & 1 & 0.706 & -0.100 \\
\hline & 0.3349 & 0.0146 & $<.0001$ & $<.0001$ & 0.0686 & 0.0124 & 0.0677 & 0.0197 & & 0.0023 & 0.7137 \\
\hline \multirow{2}{*}{$\mathrm{HCO}_{3}^{-}$} & -0.409 & 0.456 & 0.470 & 0.443 & -0.118 & 0.017 & -0.121 & -0.006 & 0.706 & 1 & 0.249 \\
\hline & 0.1647 & 0.0761 & 0.0663 & 0.0860 & 0.6623 & 0.9511 & 0.6562 & 0.9823 & 0.0023 & & 0.3530 \\
\hline \multirow{2}{*}{$\mathrm{SiO}_{2}$} & 0.140 & 0.482 & 0.008 & -0.104 & -0.128 & -0.099 & -0.130 & -0.132 & -0.100 & 0.249 & 1 \\
\hline & 0.6488 & 0.0587 & 0.9767 & 0.7026 & 0.6375 & 0.7139 & 0.6319 & 0.6273 & 0.7137 & 0.3530 & \\
\hline
\end{tabular}


Table 6. Pearson correlation coefficient (upper value) and $p$-value (lower value) of specific capacity $(Q / s)$ and chemical constituents of the igneous deep groundwater type

\begin{tabular}{cccccccccccc}
\hline \hline & $\mathrm{Q} / \mathrm{s}$ & $\mathrm{T}$ & $\mathrm{K}^{+}$ & $\mathrm{Na}^{+}$ & $\mathrm{Ca}^{2+}$ & $\mathrm{Mg}^{2+}$ & $\mathrm{Zn}^{2+}$ & $\mathrm{Cl}^{-}$ & $\mathrm{SO}_{4}^{2-}$ & $\mathrm{HCO}_{3}^{-}$ & $\mathrm{SiO}_{2}$ \\
\hline \multirow{2}{*}{$\mathrm{Q} / \mathrm{s}$} & 1 & 0.039 & -0.029 & 0.004 & -0.036 & -0.027 & 0.025 & -0.010 & -0.014 & 0.002 & 0.171 \\
& & 0.6557 & 0.7513 & 0.9651 & 0.6907 & 0.7706 & 0.7941 & 0.9126 & 0.8721 & 0.9808 & 0.0691 \\
\hline \multirow{2}{*}{$\mathrm{T}$} & 0.039 & 1 & -0.027 & 0.058 & 0.059 & -0.029 & 0.090 & 0.039 & 0.050 & 0.078 & 0.056 \\
& 0.6557 & & 0.7549 & 0.4958 & 0.4939 & 0.7406 & 0.3258 & 0.6603 & 0.5600 & 0.3692 & 0.5458 \\
\hline \multirow{2}{*}{$\mathrm{K}^{+}$} & -0.029 & -0.027 & 1 & -0.034 & 0.305 & 0.800 & -0.019 & -0.025 & 0.771 & -0.059 & -0.067 \\
& 0.7513 & 0.7549 & & 0.6938 & 0.0003 & $<.0001$ & 0.8390 & 0.7783 & $<.0001$ & 0.4965 & 0.4681 \\
\hline \multirow{2}{*}{$\mathrm{Na}^{+}$} & 0.004 & 0.058 & -0.034 & 1 & 0.784 & 0.475 & 0.434 & $\mathbf{0 . 9 6 3}$ & 0.466 & 0.104 & -0.123 \\
& 0.9651 & 0.4958 & 0.6938 & & $<.0001$ & $<.0001$ & $<.0001$ & $<.0001$ & $<.0001$ & 0.2313 & 0.1819 \\
\hline \multirow{2}{*}{$\mathrm{Ca}^{2+}$} & -0.036 & 0.059 & 0.305 & 0.784 & 1 & 0.634 & 0.329 & $\mathbf{0 . 8 7 9}$ & 0.665 & -0.046 & -0.180 \\
& 0.6907 & 0.4939 & 0.0003 & $<.0001$ & & $<.0001$ & 0.0002 & $<.0001$ & $<.0001$ & 0.6012 & 0.0488 \\
\hline \multirow{2}{*}{$\mathrm{Mg}^{2+}$} & -0.027 & -0.029 & 0.800 & 0.475 & 0.634 & 1 & 0.263 & 0.488 & 0.847 & -0.029 & -0.157 \\
& 0.7706 & 0.7406 & $<.0001$ & $<.0001$ & $<.0001$ & & 0.0047 & $<.0001$ & $<.0001$ & 0.7491 & 0.0982 \\
\hline \multirow{2}{*}{$\mathrm{Zn}^{2+}$} & 0.025 & 0.090 & -0.019 & 0.434 & 0.329 & 0.263 & 1 & 0.440 & 0.162 & 0.025 & -0.069 \\
& 0.7941 & 0.3258 & 0.8390 & $<.0001$ & 0.0002 & 0.0047 & & $<.0001$ & 0.0743 & 0.7822 & 0.4530 \\
\hline \multirow{2}{*}{$\mathrm{Cl}^{-}$} & -0.010 & 0.039 & -0.025 & $\mathbf{0 . 9 6 3}$ & $\mathbf{0 . 8 7 9}$ & 0.488 & 0.440 & 1 & 0.447 & -0.044 & -0.183 \\
& 0.9126 & 0.6603 & 0.7783 & $<.0001$ & $<.0001$ & $<.0001$ & $<.0001$ & & $<.0001$ & 0.6210 & 0.0449 \\
\hline \multirow{2}{*}{$\mathrm{SO}_{4}^{2-}$} & -0.014 & 0.050 & 0.771 & 0.466 & 0.665 & 0.847 & 0.162 & 0.447 & 1 & -0.051 & -0.183 \\
& 0.8721 & 0.5600 & $<.0001$ & $<.0001$ & $<.0001$ & $<.0001$ & 0.0743 & $<.0001$ & & 0.5556 & 0.0459 \\
\hline \multirow{2}{*}{$\mathrm{HCO}_{3}^{-}$} & 0.002 & 0.078 & -0.059 & 0.104 & -0.046 & -0.029 & 0.025 & -0.044 & -0.051 & 1 & 0.429 \\
& 0.9808 & 0.3692 & 0.4965 & 0.2313 & 0.6012 & 0.7491 & 0.7822 & 0.6210 & 0.5556 & $<.0001$ \\
\hline \multirow{2}{*}{$\mathrm{SiO}_{2}$} & 0.171 & 0.056 & -0.067 & -0.123 & -0.180 & -0.157 & -0.069 & -0.183 & -0.183 & 0.429 & 1 \\
& 0.0691 & 0.5458 & 0.4681 & 0.1819 & 0.0488 & 0.0982 & 0.4530 & 0.0449 & 0.0459 & $<.0001$ & $<.0001$ \\
\hline
\end{tabular}

Pearson correlation analysis revealed almost no relationship between $Q / s$ and the chemical constituents $\left(\mathrm{K}^{+}, \mathrm{Na}^{+}, \mathrm{Ca}^{2+}\right.$, $\mathrm{Mg}^{2+}, \mathrm{Zn}^{2+}, \mathrm{Cl}^{-}, \mathrm{SO}_{4}{ }^{2-}, \mathrm{HCO}_{3}{ }^{-}$, and $\mathrm{SiO}_{2}$ ) in the DGigneous and DG-metamorphic types (Table 6, Table 7). This no relationship can be explained by that geothermal water discharge is greatly dependent on permissive geological structure and by that long time is necessary to achieve high concentration of chemical components. In the DG-igneous type, $\mathrm{Cl}^{-}$ions showed very high linearity with $\mathrm{Na}^{+}$ $(r=0.963)$ and $\mathrm{Ca}^{2+}(r=0.879)$. This chemical relationship is similar to the case of the RM-igneous type. Pearson correlation analysis of the DG-metamorphic type showed that $\mathrm{Na}^{+}$ions have a very strong relationship with $\mathrm{Mg}^{2+}$ $(r=0.929)$ and $\mathrm{Cl}^{-}(\mathrm{r}=0.957)$ (Table 7). The result of the correlation analysis of the DG-metamorphic type is analogous to the case of the RM-metamorphic type.

Pearson correlation analysis revealed a stronger relationship between $\mathrm{Na}^{+}, \mathrm{Ca}^{2+}$, and $\mathrm{Cl}^{-}$in the igneous rock of both $\mathrm{RM}$ and DG types, whereas a stronger relationship was observed between $\mathrm{Na}^{+}, \mathrm{Ca}^{2+}, \mathrm{Cl}^{-}, \mathrm{K}^{+}$, and $\mathrm{Mg}^{2+}$ in the metamorphic rock of both RM and DG types. In addition, since some geothermal spas are located near the coast of the Korean Peninsula, the effect of saltwater was examined using $\mathrm{Na} / \mathrm{Cl}$ ratio (Fig. 8). According to the $\mathrm{Na} / \mathrm{Cl}$ ratio, Haeundae, Jeju Island, and Ganghwa Island spas belonging to the RM type are affected by saltwater. On the other side, a part of the DG-type geothermal spas in Busan City, Sacheon City, Incheon City, Inje in Gangwon Province, Jeju Island, Gunsan City, and Geoje Island demonstrate the influence of saltwater.

\subsection{Temperature and chemical constituents}

Multi-regression analysis was performed between temperature and chemical constituents $\left(\mathrm{K}^{+}, \mathrm{Na}^{+}, \mathrm{Ca}^{2+}\right.$, $\mathrm{Mg}^{2+}, \mathrm{Zn}^{2+}, \mathrm{Cl}^{-}, \mathrm{SO}_{4}{ }^{2-}, \mathrm{HCO}_{3}{ }^{-}$, and $\mathrm{SiO}_{2}$ ) of the $\mathrm{RM}$ type and DG type (Tables 4 - Table 7).

In the RM-igneous type, a remarkable relationship was not observed between the temperature and chemical constituents with Pearson correlation coefficients of 0.138 (with $\mathrm{SiO}_{2}$ ) --0.144 (with $\mathrm{SO}_{4}{ }^{2-}$ ). In the RM-metamorphic 
Table 7. Pearson correlation coefficient (upper value) and $p$-value (lower value) of specific capacity $(Q / s)$ and chemical constituents of the metamorphic deep groundwater type

\begin{tabular}{|c|c|c|c|c|c|c|c|c|c|c|c|}
\hline & $\mathrm{Q} / \mathrm{s}$ & $\mathrm{T}$ & $\mathrm{K}^{+}$ & $\mathrm{Na}^{+}$ & $\mathrm{Ca}^{2+}$ & $\mathrm{Mg}^{2+}$ & $\mathrm{Zn}^{2+}$ & $\mathrm{Cl}^{-}$ & $\mathrm{SO}_{4}^{2-}$ & $\mathrm{HCO}_{3}^{-}$ & $\mathrm{SiO}_{2}$ \\
\hline \multirow{2}{*}{$\mathrm{Q} / \mathrm{s}$} & 1 & 0.145 & -0.060 & -0.050 & -0.015 & -0.048 & -0.104 & -0.038 & -0.013 & -0.067 & 0.108 \\
\hline & & 0.2420 & 0.6432 & 0.6992 & 0.9071 & 0.7176 & 0.4155 & 0.7681 & 0.9183 & 0.6049 & 0.3995 \\
\hline \multirow{2}{*}{$\mathrm{T}$} & 0.145 & 1 & -0.164 & -0.140 & -0.068 & -0.117 & -0.008 & -0.123 & 0.058 & -0.148 & -0.028 \\
\hline & 0.2420 & & 0.1848 & 0.2575 & 0.5873 & 0.3556 & 0.9510 & 0.3228 & 0.6452 & 0.2370 & 0.8198 \\
\hline \multirow{2}{*}{$\mathrm{K}^{+}$} & -0.060 & -0.164 & 1 & 0.840 & 0.579 & 0.733 & 0.755 & 0.785 & 0.576 & 0.392 & 0.174 \\
\hline & 0.6432 & 0.1848 & & $<.0001$ & $<.0001$ & $<.0001$ & $<.0001$ & $<.0001$ & $<.0001$ & 0.0011 & 0.1590 \\
\hline \multirow{2}{*}{$\mathrm{Na}^{+}$} & -0.050 & -0.140 & 0.840 & 1 & 0.665 & 0.929 & 0.700 & 0.957 & 0.692 & 0.047 & -0.204 \\
\hline & 0.6992 & 0.2575 & $<.0001$ & & $<.0001$ & $<.0001$ & $<.0001$ & $<.0001$ & $<.0001$ & 0.7062 & 0.0982 \\
\hline \multirow{2}{*}{$\mathrm{Ca}^{2+}$} & -0.015 & -0.068 & 0.579 & 0.665 & 1 & 0.370 & 0.366 & 0.836 & 0.653 & -0.011 & -0.302 \\
\hline & 0.9071 & 0.5873 & $<.0001$ & $<.0001$ & & 0.0026 & 0.0023 & $<.0001$ & $<.0001$ & 0.9302 & 0.0131 \\
\hline \multirow{2}{*}{$\mathrm{Mg}^{2+}$} & -0.048 & -0.117 & 0.733 & 0.929 & 0.370 & 1 & 0.737 & 0.798 & 0.626 & 0.052 & -0.136 \\
\hline & 0.7176 & 0.3556 & $<.0001$ & $<.0001$ & 0.0026 & & $<.0001$ & $<.0001$ & $<.0001$ & 0.6847 & 0.2840 \\
\hline \multirow{2}{*}{$\mathrm{Zn}^{2+}$} & -0.104 & -0.008 & 0.755 & 0.700 & 0.366 & 0.737 & 1 & 0.596 & 0.702 & 0.338 & 0.109 \\
\hline & 0.4155 & 0.9510 & $<.0001$ & $<.0001$ & 0.0023 & $<.0001$ & & $<.0001$ & $<.0001$ & 0.0056 & 0.3793 \\
\hline \multirow{2}{*}{$\mathrm{Cl}^{-}$} & -0.038 & -0.123 & 0.785 & 0.957 & 0.836 & 0.798 & 0.596 & 1 & 0.687 & -0.042 & -0.298 \\
\hline & 0.7681 & 0.3228 & $<.0001$ & $<.0001$ & $<.0001$ & $<.0001$ & $<.0001$ & & $<.0001$ & 0.7385 & 0.0142 \\
\hline \multirow{2}{*}{$\mathrm{SO}_{4}{ }^{2-}$} & -0.013 & 0.058 & 0.576 & 0.692 & 0.653 & 0.626 & 0.702 & 0.687 & 1 & -0.016 & -0.157 \\
\hline & 0.9183 & 0.6452 & $<.0001$ & $<.0001$ & $<.0001$ & $<.0001$ & $<.0001$ & $<.0001$ & & 0.8977 & 0.2081 \\
\hline \multirow{2}{*}{$\mathrm{HCO}_{3}^{-}$} & -0.067 & -0.148 & 0.392 & 0.047 & -0.011 & 0.052 & 0.338 & -0.042 & -0.016 & 1 & 0.478 \\
\hline & 0.6049 & 0.2370 & 0.0011 & 0.7062 & 0.9302 & 0.6847 & 0.0056 & 0.7385 & 0.8977 & & $<.0001$ \\
\hline \multirow{2}{*}{$\mathrm{SiO}_{2}$} & 0.108 & -0.028 & 0.174 & -0.204 & -0.302 & -0.136 & 0.109 & -0.298 & -0.157 & 0.478 & 1 \\
\hline & 0.3995 & 0.8198 & 0.1590 & 0.0982 & 0.0131 & 0.2840 & 0.3793 & 0.0142 & 0.2081 & $<.0001$ & \\
\hline
\end{tabular}
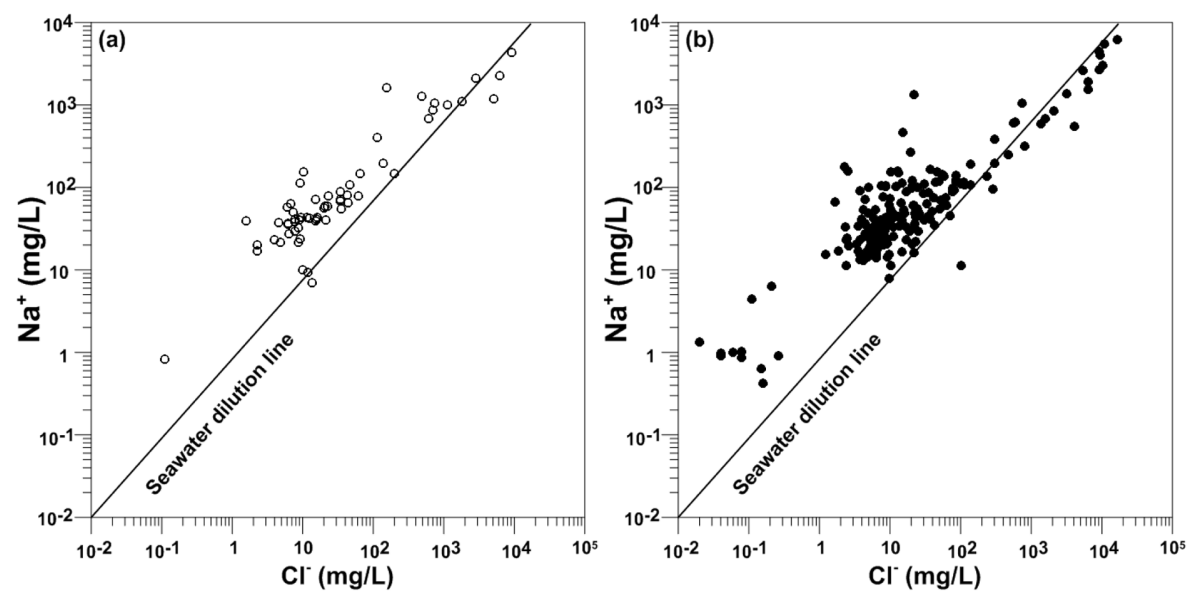

Fig. 8. Relationship between sodium and chloride for (a) residual magma type and (b) deep groundwater type.

type, the high Pearson correlation coefficient of 0.675 between temperature and $\mathrm{K}^{+}$was significant. On the other hand, the DG-igneous type and DG-metamorphic type showed even lower Pearson correlation coefficients of 0.058 (with $\mathrm{SO}_{4}{ }^{2-}$ ) - -0.164 (with $\mathrm{K}^{+}$). This low relationship between the temperature and chemical constituents may designate the non-volcanic origin of the geothermal waters. Moreover, this low relationship between temperature and chemical constituents suggests mixing effect on the geothermal water of the RM type (Park et al., 2006).

Resultantly, weak relationship between temperature and chemical constituents was found for both the RM type and 
DG type. By contrast, temperature in the RM- and DGmetamorphic types showed a little stronger relationship with $\mathrm{Na}^{+}, \mathrm{Ca}^{2+}, \mathrm{Cl}^{-}, \mathrm{K}^{+}$and $\mathrm{Mg}^{2+}$ concentrations, indicating abundant mafic minerals in the metamorphic rocks.

\section{Discussion and conclusions}

Korea has only non-volcanic residual magma (RM) type and deep groundwater (DG) type geothermal waters according to the division of $35^{\circ} \mathrm{C}$ because Korea is located distantly from the convergent plate boundaries. Nevertheless, Korea has more than 400 geothermal spas with temperatures of $25-76^{\circ} \mathrm{C}$. In this study, a total of $281 \mathrm{RM}$ and the DG geothermal waters occurring in igneous and metamorphic rock areas were reviewed in terms of the specific capacity, water temperature, and chemical constituents $\left(\mathrm{K}^{+}, \mathrm{Na}^{+}\right.$, $\mathrm{Ca}^{2+}, \mathrm{Mg}^{2+}, \mathrm{Zn}^{2+}, \mathrm{Cl}^{-}, \mathrm{SO}_{4}{ }^{2-}, \mathrm{HCO}_{3}{ }^{-}$, and $\mathrm{SiO}_{2}$ ).

Considering the lengths of the longest faults near the geothermal hole, the distance from the hole to the longest fault, number of sub-faults crossing the longest fault, and total length of the sub-faults, the average length of the longest fault in the RM type area was found to be $\sim 9 \mathrm{~km}$ longer than that in the DG type area. On the other hand, the distance from the hole to the longest fault, the number of sub- fault $\mathrm{s}$ crossing the longest fault, and the total length of the sub- fault s were analogous for the RM type area and the DG type area, suggesting that the length of the longest fault is the main parameter determining the vertical movement and temperature of geothermal water. Therefore, the RM type is linked more strongly to higher geothermal heat.

A negligible relationship between the specific capacity $(Q / s)$ and temperature was observed for both the RM type and DG type. Nevertheless, the specific capacities of the RM- and DG-igneous types were greater than those of the RM- and DG-metamorphic types. The RM-type and DGtype showed almost no relationship between $Q / s$ and the chemical constituents $\left(\mathrm{K}^{+}, \mathrm{Na}^{+}, \mathrm{Ca}^{2+}, \mathrm{Mg}^{2+}, \mathrm{Zn}^{2+}, \mathrm{Cl}^{-}\right.$, $\mathrm{SO}_{4}{ }^{2-}, \mathrm{HCO}_{3}^{-}$, and $\mathrm{SiO}_{2}$ ), being explained by that geothermal water discharge is greatly dependent on permissive geological structure and by that long time is necessary to achieve high concentration of chemical components. Weak relationship between temperature and chemical constituents was found for both the RM type and DG type whereas temperature in the RM- and DGmetamorphic types showed a little stronger relationship with $\mathrm{Na}^{+}, \mathrm{Ca}^{2+}, \mathrm{Cl}^{-}, \mathrm{K}^{+}$and $\mathrm{Mg}^{2+}$ concentrations, representing abundant mafic minerals in the metamorphic rocks.

\section{Acknowledgements}

This research was supported by Basic Science Research Program through the National Research Foundation of Korea (NRF) funded by the Ministry of Education (NRF2013R1A1A2058186).

\section{References}

Bae, D.-J., Yum, B.W., Kim, O.-W., and Lee, C.W., 1992, Report of Sokcho (Jangsa) spa, KIGAM (Korea Institute of Geoscience and Mineral Resources), 84 p.

Bae, D.-J. and Lee, C.W., 1993, Report of Goseong (Wonam 4) spa, KIGAM (Korea Institute of Geoscience and Mineral Resources), $60 \mathrm{p}$.

Chang, C.C., Kim, K.H., and Kong, Y.S., 1970, Heat flow in Korea, Korea Research Institute of Geoscience and Mineral Resources, Report on Geophysical and Geochemical Exploration, 4(1), 30-37.

Cho, B.W., Park, J.W., 1991, Report of Yesan spa, KIGAM (Korea Institute of Geoscience and Mineral Resources), 23 p.

Chough, S.K., 2013, Geology and Sedimentology of the Korean Peninsula, Elsevier, 348 p.

Jeon, H.T., Moon, H.S., Kim, G.H., Jeong, M.C., 1998, Environmental Geology, Press of Seoul National University, 529 p.

Han, S.J., Hamm, S.-Y., Sung, I.H., Lee, B.D., Cho, B.W., and Cho, M.H., 1999, Geochemical characteristics of geothermal water and groundwater in the Dongrae hot-spring area, J. Eng. Geol., 9(3), 207-225.

Kim, G.H., 2007, Hot spring of Korea, Press of Ewha Women's University, $238 \mathrm{p}$.

Kim, G.H. and Choi, H.J., 1998, A geochemical study on the thermal water and groundwater in the hot spring area, South Korea, J. Korean. Earth Sci. Soc., 19(1), 22-34.

Kim, H.C., Yum, B.W., and Lee, J.C., 2001, Report of Dalseong spa, KIGAM (Korea Institute of Geoscience and Mineral Resources), 67 p.

Kim, H.C., Lee, J.C., Lee, C.O., and Song, J.Y., 1995, Report of Sokcho (Nohak) Spa, KIGAM (Korea Institute of Geoscience 
and Mineral Resources), $80 \mathrm{p}$.

Kim, H.C. and Lee, Y., 2007, Heat flow in the Republic of Korea, J. Geophy. Res., 112, doi: 10.1029/2006JB004266.

Koh, S.-M., Ryoo, C.-R., and Song, M.-S., 2003, Mineralization characteristics and structural controls of hydrothermal deposits in the Gyeongsang Basin, South Korea, Resour. Geol., 53(3), 175-192.

Korea Institute of Energy and Resources, 1995, Geological Map of Korea.

Lee, D.S., 1987, Geology of Korea, The Kyohak-Sa Publishing Co., 514 p.

Lee, Y., Park, S., Kim, J., Kim, H.C., and Koo, M.-H., 2010, Geothermal resource assessment in Korea, Renenw. Sust. Energ. Rev., 14, 2392-2400.

Lim. J.U., 1995, Geothermal potential in the Republic of Korea, in Terrestrial Heat Flow and Geothermal Energy in Asia ed. by Gupta, M.L. and Yamano, M., Oxford \& IBH Publishing Co., Pvt., Ltd., New Delhi, 435-467.

Lim, J.U., Yum, B.W., Lee, S.G., Kim, H.C., Chwae, U., Choi, S.J., Choi, D.R., Lee, S.G., Hwang, S.H., and Park, I.H., 1996, Report of Chungju (Suanbo) Spa, KIGAM (Korea Institute of Geoscience and Mineral Resources), $178 \mathrm{p}$.

Lim. J.U., Choi, B.-W., and Park, J.K., 1992a, Report of Goseong (Wonam) Spa, KIGAM (Korea Institute of Geoscience and Mineral Resources), 143 p.

Lim, J.U., Lee, D.-Y., Kim, Y.-K., Choi, Y.-S., Yum, B.W., and Lee, J.M., 1992b, Report of Busan (Dongrae) Spa, KIGAM (Korea Institute of Geoscience and Mineral Resources), 234 p.

Lim, J.U., Choi, B.-W., Lee, B.J., Seong, K.S., and Kim, S.Y., 1991, Report of Duksan (Sinpyeong) Spa, KIGAM (Korea Institute of Geoscience and Mineral Resources), $73 \mathrm{p}$.

Lim, J.U., Choi, B.-W., Lee, B.J., Kim, H.C., and Kim, S.Y., 1990a, Report of Duksan (Doonri) Spa, KIGAM (Korea Institute of Geoscience and Mineral Resources), $44 \mathrm{p}$.

Lim, J.U., Choi, B.-W., Lee, B.J., Seong, K.S., and Kim, S.Y., 1990b, Report of Duksan (Siryang 29-22) Spa, KIGAM (Korea Institute of Geoscience and Mineral Resources), $46 \mathrm{p}$.

Lim, J.U., Choi, B.-W., Lee, B.J., Song, K.Y., Seong, K.S., and Kim, S.H., 1990c, Report of Duksan (Siryang 29-16) Spa, KIGAM (Korea Institute of Geoscience and Mineral Resources), $46 \mathrm{p}$.

Lim, J.U., Hong, S.H., Choi, B.Y, Jeong, S.H., Kim, J.H., Seo, J.Y., Jeon, J.S., Lee, S.H., Hamm, S.-Y., Choi, Y.S., Kim, H.C., Yum, B.W., Jo, B.W., Kim, S.Y., Seong, G.,S., Gu, S.H., and Koh, I.S., 1989, Report of geothermal resource survey in Bugok Spa area, KIGAM (Korea Institute of Geoscience and Mineral Resources), $183 \mathrm{p}$.
Lim. J.U., Hamm, S.-Y., Choi, B.-W., and Kim, H.C., 1988a, Report of Duksan (Siryang 27-8) Spa, KIGAM (Korea Institute of Geoscience and Mineral Resources), 57 p.

Lim, J.U., Choi, B.-W., Kim, H.C., and Yum, B.W., 1988b, Report of Duksan (Sadong \& Sryang) Spa, KIGAM (Korea Institute of Geoscience and Mineral Resources), $135 \mathrm{p}$.

Lim, J.U., Sung, I.B., Hamm, S.-Y., Lee, S.I., and Cho, B.W., 1987, Report of OnYang spa, KIGAM (Korea Institute of Geoscience and Mineral Resources), $78 \mathrm{p}$.

Ministry of Interior, 1988, Report on hot spring, $722 \mathrm{p}$.

Mizutani, H., Baba, K., Kobayashi, N., Chang, C.C., Lee, C.H., and Kang, Y.S., 1970, Heat flow in Korea, Tectonophys., 10, 1820.

Moon, S.H., Lee, C.W., Seong, G.S., and Yum, B.W., 1999, Report of Masan (Yangcheon) Spa, KIGAM (Korea Institute of Geoscience and Mineral Resources), 48 p.

Moon, S.H., Lee, C.W., Sung, K., Koh, D-C., Kim, Y-K., Shin, H.M., and Koh, I.S., 2000, Report of Busan (Jangjeon) Spa, KIGAM (Korea Institute of Geoscience and Mineral Resources), $81 \mathrm{p}$.

Moon, S.H., Kim, S.J., Hwang, H.S., Ki, W.S., Koh, D.-C., Ha, G.C., Seong, K.S., Yum, B.W., Lee, C.W., Choi, M.J., and Lee, T.S., 2001, Report of Yongam spa, KIGAM (Korea Institute of Geoscience and Mineral Resources), 259 p.

Papazachos, B.C., 1996, Large seismic faults in the Hellenic arc, Ann. Geofis., 39, 891-903.

Park, S.-S., Yun, S.-T., Chae, G.-T., Hutcheon, I., Koh, Y.-K., So, C.-S., and Choi, H.-S., 2006, Temperature evaluation of the Bugok geothermal system, South Korea, Geothermics, 35(4), 448-469.

Sim, H.S., Hamm, S.-Y., Seong, I.H., Lee, B.D., Choi, B-W., and Hwang, J.Y., 2000, A study on the geochemical characteristics of thermal- and ground-water in Haeundae-gu, Busan, Korea, J. Environ. Sci., 9(3), 241-252.

Smith-Konter, B.R., Sandwell, D.T., and Shearer, P., 2011, Locking depths estimated from geodesy and seismology along the San Andreas Fault System: Implications for seismic moment release, J. Geophy. Res. 116, doi:10.1029/2010JB008117.

Tamanyu, S., 1985, Geothermal heat in Korea, Geo. News, 366, 50-57.

Wells, D.L. and Coppersmith, K.J., 1994, New Empirical Relationships among Magnitude, Rupture Length, Rupture width, rupture area, and surface displacement, Bull. Seismol. Soc. Am., 84, 974-1002.

Yum, B.W., 1991, Report of Pocheon spa, KIGAM (Korea Institute of Geoscience and Mineral Resources), 57 p. 
Yum, B.W. and Bae, D.-J., 1991, Report of Sokcho (Nohak) Spa, KIGAM (Korea Institute of Geoscience and Mineral Resources), $63 \mathrm{p}$.

Yum, B.W., Bae, D.-J., and Kim, O-W., 1992, Report of Sokcho (Nohak) Spa, KIGAM (Korea Institute of Geoscience and Mineral Resources), $65 \mathrm{p}$.
Yum, B.W., Kim, O.-W., Chwae, U., Kim, H.C., Im, H.C., and Lee, S.-G., 1994, Report of Sokcho (Seolack Praza) Spa, KIGAM (Korea Institute of Geoscience and Mineral Resources), $103 \mathrm{p}$.

Yum, B.W., Bae, D.J., and Seong, K.S., 1996, Report of Pohang (Hakya) Spa, KIGAM (Korea Institute of Geoscience and Mineral Resources), $57 \mathrm{p}$. 